Золтан Ђере

Универзитет у Новом Саду

Филозофски факултет

Одсек за историју

zoltan.gyore1@gmail.com
Оригиналан научни рад

примљено: 17. мај 2014

прихваћено: 1. октобар 2014

\title{
РАТОВИ И СТАНОВНИШТВО УГАРСКЕ 1521-1718.
}

Сажетак: Доба османске власти у деловима Угарске обично се оцењује као најгори период историје те земље услед распада државе, назадовања привредних и друштвених прилика, а надасве услед маркантних демографских губитака.

Услед 21 рата вођеног на територији Угарске у периоду 1521-1718, број становника је стагнирао чак и уз масовно усељавање са Балкана, док је уз све недаће као и људске губитке Тридесетогодишњег рата европски просек пораста броја становника износио близу $60 \%$. Као резултат тешких разарања мрежа насеља битно је проређена и структурално измењена. Такође, због ратова и имиграције сразмера Мађара у етничкој структури становништва земље опала је са $75-80 \%$ на $50 \%$. Резултат тога било је настајање изразито мултиетничког друштва, са свим проблемима које једно вишенационално друштво може задесити у доба национализма.

Кључне речи: Османска империја, Хабзбуршка монархија, Угарска, историјска демографија, број становника, ратови, Војводина, миграције, насеља.

Увод

Карловачки мир у историји Краљевине Мађарске једна је од најважнијих историјских прекретница. После више од века и по готово цела територија Угарске ослобођена је од османске власти и уједињена под једним жезлом. Спорна питања у односима мађарских сталежа и бечког двора решена су компромисним Сатмарским миром на крају Ракоцијевог устанка (1703-1711), а Пожаревачки мир (1718) окончао је ослобођење Угарске и протеривање Османлија из Средње Европе. Могло се коначно почети са обновом и реинтеграцијом тешко разорене и дуго времена подељене Угарске, време је било за материјалну и духовну обнову.

Период владавине Османске империје у средишњим и јужним деловима Мађарске пружа прворазредну прилику историчарима за проучавање учинка дуготрајних ратних прилика на одређену државу и друштво као и за истраживање проблема прилагођавања становништва таквим условима живота. Ратовало се често и у другим деловима савремене Европе, али нам се чини да је Мађарска била специфична по томе, да су у њој борбе вођене непрестано, чак и у периодима 
формално мирних односа. У раду ћемо се укратко посветити општем утицају османске власти и ратова 1521-1718. на базична демографска дешавања у Угарској.

Краљевина Мађарска је од 1366. до Мохачке битке ратовала 11 пута са османском државом и заједно са балканским народима и Млетачком републиком сматрана је за важног браниоца хришћанства и Европе (antemurale christianitatis, односно „штит хришћанства”, како су папе Никола V, Каликст III и Пије II називали Мађарску). ${ }^{1}$ После одлучујућег пораза угарских снага код Мохача 1526. територија Краљевине Мађарске постала је бојно поље две најјаче империје тадашње Европе, Хабзбуршке и Османске. Иако више није била самостални субјекат противосманске борбе, Угарска је остала важан бастион одбране од продора Османлија у Европу, а истакнута улога средњег Подунавља у ратним плановима Османске империје донела joj је велик број ратова и тешка пустошења после 1526. године. Султан Сулејман Величанствени водио је седам великих похода у Мађарску $(1521,1526,1529,1532$, 1540-1547, 1550-1558. и 1564-1566) са циљем да је потчини и освоји Беч. После Сулејманових похода беснели су Петнаестогодишњи аустро-турски рат (1591-1606), Велики рат (1663-1664), па Бечки или Дуги рат (1683-1699) и аустро-турски рат 1716-1718. године. Пошто је независно од поменутих војних конфликата и Кнежевина Ердељ ратовала са Турском (1612-1613, 1636, 1658-1662), можемо констатовати да је на територији Угарске 1521-1718. г. са Османском империјом вођено 14 ратова, укупног трајања преко шездесет година. Као да то није било довољно, мађарски и ердељски сталежи су ради очувања суверенитета угарске сталешке државе и гаранција слободе вероисповедања протестаната седам пута (1604-1606, 1618-1621, 1623-1624, 1626, 1644-1645, 1672-1685. и 1703-1711) заратили на Хабзбурге, са укупним трајањем борби од приближно 31 године. Свеукупно, у поменутом раздобљу, био је 21 рат са укупним трајањем од 93 године; у просеку, рат је беснео сваке друге године! ${ }^{2}$

Демографски учинак поменутих ратова веома тешко је утврдити. Уз уобичајене методолошке проблеме са историјским изворима из тог доба, проблем представља рашчлањивање утицаја ратних околности од разних негативних околности климатолошког, цивилизацијског, здравственог или привредног карактера, односно питања у вези са индиректним и директним демографским губицима узрокованих ратовањем. Ипак, највише главобоља задаје чињеница да не постоје адекватни, поуздани и систематски историјски извори у вези са бројем становника који би покривали целу посматрану област, те су истраживачи упућени на процене базиране претежно на фрагментарним подацима. У том смислу, могуће је извођење

\footnotetext{
* Текст је настао као фазни резултат рада на пројекту Војвођански простор у контексту европске историје (број 177002) Министарства просвете, науке и технолошког развоја Републике Србије. Уједно, тема представља фазни резултат рада у оквиру Програма за унапређење квалитета наставе Филозофског факултета у Новом Саду.

${ }^{1}$ Vecsey Lajos, Az imádságok bullája és A déli harangszó, Genessenschafts-Buchdruck, 1955, 32.

2 При томе противхабзбуршки ратови и устанци одвијали су се претежно у областима које су дотад углавном биле поштеђене османских напада. Сходно томе и реторзије хабзбуршке војске током Бечког рата и Ракоцијевог устанка биле су израженије према мађарском становништву поменутих области него другде. H. Németh István., Háború és népesség a kora újkori Magyarországon (16-17. század), Budapest 2001, 140.
} 
различитих закључака у зависности од различитих полазних података и методолошких поставки. ${ }^{3}$

Мађарска историографија је од друге половине XIX века посветила велик број публикација питањима демографских односа у периоду османске власти. При томе се процене историчара у вези са кретањем броја становника доста разликују, али се ипак може стећи генерална слика о главним правцима промена у разматрано време. Треба нагласити да сем у проценама појединих историчара, постоје добро уочљиве систематске разлике у проценама разних генерација историчара: у периоду између два светска рата обично се рачунало са малим бројем становника и огромним људским губицима, од шездесетих година су настали радови који су процењивали број становништва Угарске на веће бројке, а од краја деведесетих се поново размишља о мањим бројкама. Те промене, по мишљењу Ђерђа Гранастоија, имају везе са процесима настајања научног мишљења, односно са специфичним консензусима међу историчарима одређене епохе, што је само по себи интересантно историографско питање. ${ }^{4}$

\section{Директни људски губици}

Бројни ратови 1521-1718. ударили су печат збивањима у претежном делу Угарске. Ратне прилике и ратна пустошења у знатној мери одређивали су размишљање и начин живота људи тога доба и имали су судбоносне последице по саму угарску државу, њену привреду, друштвене односе, менталитет становништва и општи културни и цивилизацијски развој. Мађарски историчари углавном се слажу у констатацији да су најдалекосежније и најтрагичније последице изазвали људски губици. Ни издалека не познајемо тачан број погинулих у биткама, убијених, одведених у ропство или умрлих у епидемијама и од болести које су се шириле у вези са покретима великих војски, али судећи на основу укупног демографског

\footnotetext{
3 Све до јозефинског генералног пописа становништва из 1785. на располагању историчара стоје конскрипције опорезованог становништва, обично на нивоу старешина породица, састављене за потребе цркве, државе или властеле (десетински пописи, урбари, порески пописи, пописи поседа, у новом веку тзв. пописи душа).

Додатан проблем процене становништва представља околност да су услед ратних дејстава мање или веће групе становника често биле у покрету, али и чињеница да ни хришћанској ни османској властели није било у интересу да држави саопшти реалну слику о броју и иметку подложног становништва. Слично, индиректне и директне ратне губитке немогуће је тачно одредити с обзиром на велик обим прилива имиграната из суседних земаља на територију Ердеља и Мађарске, о чему такође имамо само делимичне и посредне податке.

Незаобилазно а компликовано питање приликом процене броја становника на основу пописаног броја старешина породица јесте питање фактора којим се тај број множи. Примера ради, у вези са пописом из 1494-1495. врсни познаваоци проблематике, Иштван Сабо и Андраш Кубињи, користили су различите факторе множења (5 односно 6,2), што је на 266.000 домаћинстава чинило разлику од близу 221.666 лица. А. Кубињи примећује да у вези са бројем чланова породице треба водити рачуна између осталог о чињеници да је старост ступања у брак, животни век и број деце био у корелацији са социјалним статусом особе. Kubinyi András, A késö-középkori Magyarország történeti demográfiai problémái,Történeti Demográfiai Évkönyv, Budapest 2001, 105.

${ }^{4}$ Granasztói György, Történelem és történetírás. Jegyzet arról, hogyan változik az ország lélekszáma hosszú időtartam alatt, Történeti Demográfiai Évkönyv, Budapest 2005, 19; Font Márta, A honfoglalástól Mohácsig, A Kárpát-medence etnikai és demográfiai viszonyai a honfoglalástól a török kiüzéséig (Ed. Font Márta), Pécs 1998, 4-6.
} 
учинка, морамо закључити да су губици били превелики. На проређење становништва највише су утицали ратови и пограничне чарке са Османлијама, али такође морамо бити свесни чињенице да су осетне губитке током посматраног период изазвали хабзбуршко-мађарски сукоби, а нарочито Ракоцијев устанак.

Специфичност ратовања у Угарској је чињеница да ни формални периоди мира, попут оних 1569-1591, 1606-1657. и 1664-1684, нису донели истински мир становништву. Практично, у тим периодима главне армије сучељених страна нису дејствовале на бојишту, али су пограничне борбе и упади на непријатељску територију и даље трајали, при чему су неретко продори вршени дубоко иза граничне линије. Циљ упада била је пљачка, убирање пореза или деморалисање противника, а годишњи губици су износили неколико стотина до неколико хиљада погинулих и сличан број отераних у ропство. Посматрано кумулативно у десетогодишњем или дужем интервалу, чарке су изазивале озбиљне људске и материјалне губитке. ${ }^{5}$

Људски губици и разарања које су узроковали походи султана Сулејмана Величанственог били су упоредиви само са Татарском најездом на Угарску 1241/1242. г., но ипак, они нису изазвали толико уништења као два дуга рата (1591-1606. и 1683-1699) и Ракоцијев устанак. Током XVI века, после Сулејманових похода разбежало становништво се враћало из тврђава, мочвара и шума у своја насеља и поново градило домове, набављало стоку и обнављао послове на ораници. Становништво је у односу на тежину околности показивало изненађујући степен виталности и регенеративне моћи, међутим ратови у којима су велике војске дугих година непрекидно боравиле на бојишту, узроковали су материјалне, духовне и демографске губитке таквог обима да их није било могуће санирати ни на дуже стазе. За разлику од ратова султана Сулејмана који су погађали одређене делове земље и трајали годину-две, поменути ратови одвијали су се уз учешће армија од по педесетак и више хиљада војника, на комплетној државној територији, а пустошења су се понављала сваке године.

У том смислу граничну линију представља Петнаестогодишњи рат, чија је разорна моћ превазишла све дотад виђено у Угарској, и узроковала је губитке који су премашивали укупне губитке дотадашњег ратовања са Османлијама. О катастрофалним размерама уништења говори податак да су од стране Татара највише похарана јужна област земље и деценијама касније била готово потпуно ненастањена, некултивисана и да је на „срећнијим“ областима у северним деловима међуречја Дунава и Тисе оживела само трећина села из XVI века. Становништво разорених насеља се окупило у већа трговишта (Цеглед, Кечкемет, Нађкереш), међутим број становништва поменутих насеља ни на тај начин није достигао предратни ниво. На областима Краљевске Мађарске је тада по веома опрезним прорачунима историчара опустело близу $25 \%$ кметовских порти. Насеља на којима је живот после завршетка рата обновљен била су мања, неотпорнија и сиромашнија него пре Дугог рата. Бројна дотад значајна трговишта која су играла улогу

\footnotetext{
${ }^{5}$ Zimányi Vera, Gazdasági és társadalmi fejlödés Mohácstól a 16. század végéig, Magyarország története 1526-1686, (Ed. Pach Zsigmond Pál),I, Budapest 1987, 285-286.
} 
тржишних центара, после рата су оживела као безначајна села, што је узроковало тешкоће у привредној структури земље. Практично, у неким деловима Угарске мрежа насеља потпуно је уништена, на другим местима претрпела је ненадокнадиве штете, а ни најпоштеђеније области нису прошле без тешких разарања. При томе број становника и густина становништва осетно је опала. ${ }^{6}$ Приметимо да су пустошења изазивана од стране царске војске или, касније, Бетленових трупа била готово исто тако штетна као османска. ${ }^{7}$ По величини људских губитака и мери пропадања насеља разорнији од Петнаестогодишњег рата био је само Бечки рат 1683-1699, који се иначе у историји Угарске обично сматра најпогубнијим походом после Татарске најезде. ${ }^{8}$

Најраније и највеће губитке бележиле су јужне области Мађарске и источне хрватске територије. Османски упади на ове области догађали су се од 1380. године па надаље. Дуготрајно погранично ратовање пре 1526 . г. изазвало је веома осетна разарања, при чему су насеља која су преживела те сукобе већином изгубила своје становништво у серији великих похода султана Сулејмана Величанственог после Мохачке битке. ${ }^{9}$ Према резултатима новијих истраживања, на јужним просторима међуречја Дунава и Тисе и у приобаљу Дунава, до средине XVI века пропало је невероватних 70-90\% насеља. Када се од друге половине XVI века тежиште ратовања пренело на средишње и западне делове земље, и ту су настала тешка разарања, али не у оној мери као на југу земље. Чини се да је разлог томе изградња одбрамбеног система граничних утврда, који је и по европским мерилима био значајан, и који је добрим делом апсорбовао енергију османских напада. ${ }^{10}$

Новије публикације укупан број ратних губитака становништва током периода османске власти процењују доста ниже од ранијих историјских дела и самих савременика догађаја и обично се наводе бројке од 650.000 до 800.000 лица, без жртава епидемија. ${ }^{11}$

\section{Епидемије као пратиоци ратова}

Историјски демографи обично сматрају да су епидемије које су шириле војске покосиле пуно више људи него сама ратна дејства. У том контексту, мађарска историографија све чешће поставља питање у којој мери су епидемије и болести имале удела у негативном демографском салду посматраног раздобља. Узмемо ли у обзир да је смртоносних епидемија било пре и после периода који разматрамо, али да толиких демографских губитака ипак није било, разлоге негативног прираста треба да тражимо у великом броју ратова и компликацијама које су ти ратови

\footnotetext{
${ }^{6}$ Золтан Ђере, Од Мохачке битке до смрти ияара Јозефа II, Историја Мађара (П. Рокаи, З. Ђере, Т. Пал, А. Касаш), Београд 2002, 243-245.

${ }^{7}$ Pálffy Géza, A másfél évszázadnyi török uralom mérlege. A törökkor fordulópontjai 1, Múlt-kor, Internet časopis, 2001, 3. бp., http://www.mult-kor.hu. 12.05.2014.

${ }^{8}$ Tóth István György, A felszabaditó háborúk, Nagy képes milléniumi hadtörténet (Ed. Rácz Árpád), Budapest, 2008, 213.

${ }^{9}$ Pálffy G., Op. cit.

${ }^{10}$ Ibidem.

${ }^{11}$ H.Németh I., Op. cit., 140.
} 
узроковали.

Чињеница ипак јесте да су готово незаобилазни пратиоци ратова и кретања великих војски биле разне болести, епидемије куге и глад. За појаву епидемије у Угарској околности су биле више него повољне: чести ратови повећавали су вероватноћу да ће страна војска донети какву заразу (са османским војскама готово редовно стизала је и куга), а њихови покрети кроз целу земљу, сам начин живота у војним логорима (нехигијенски услови, немаштина, низак општи ниво хигијенских услова и медицинског знања) подстицали су ширење заразних болести и настанак великих епидемија. ${ }^{12}$

Највећи број жртава узроковала је куга која је у Мађарској у периоду 1500-1771. године харала 11, а у Ердељу 18 пута, готово увек паралелно са ратним дејствима. ${ }^{13}$ Нарочито је критична била прва половина XVIII века када су земљу погодиле две веома тешке епидемије куге, 1708-1711. и 1738-1742, односећи укупно најмање пола милиона живота. У годинама куге смртност је била 4-12 пута виша него обично, при чему се морталитет погођеног становништва кретао у распону $10-50 \% .^{14}$

Уз кугу, дубоко у XVIII век, бројне смртне случајеве изазивали су маларија, дизентерија, туберкулоза, велике богиње и тифус. ${ }^{15}$ Од XVI века лепра се повукла, а уместо ње јављао се сифилис (morbus Gallicus), а у мочварним и због ратова запуштеним областима Мађарске и специфична morbus Hungaricus. Према савременицима, реч је о страшној болести, својеврсној мешавини тифуса, маларије и дизентерије која је у околностима временских екстрема, слабих хигијенских прилика и разних паразита из локалних мочвара погађала првенствено војнике и најчешће је имала фаталан исход. ${ }^{16}$

На негативне демографске трендове додатно су утицале страшне друштвене околности везане за тешке сукобе по верској основи између католика и протестаната, тешко тлачење цивила од стране војних власти на територијама Краљевске Мађарске 1671-1711, када су многи понижавани, злостављани, протеривани и мучени. Бројне породице су се распале, било је језивих злодела против жена, деце, трудница, одвођења у ропство на галије, и сл. Постојале су и верске препреке: како раскинути брак, основати нову породицу ако је брачни друг нестао у немирним временима у којима његова смрт није могла бити потврђена? Жене су десетковане компликацијама у вези са порођајем, мушкарци од претеране употребе алкохола (у недостатку добре пијаће воде то је чак некад било нужно). Једва $10 \%$ становника доживљавало је своју 60. годину живота. Реалан просечни животни век био је око 30

\footnotetext{
12 Faragó Tamás, Bevezetés a történeti demográfiába, Budapesti Corvinus Egyetem, електронска књига, http://www.tankonyvtar.hu/en/tartalom/tamop425/0010_2A_09_Farago_Tamas_Bevezetes_a_torteneti_demograf iaba/ch06s02.html. 12.05.2014.

${ }^{13}$ Faragó Tamás, Adatok a pestisjárványok magyarországi történetéhez, Korall, 8. год., бр. 30, Budapest 2007, 30.

14 Öri Péter, A pestisjárványok demográfiai következményei a 17-18. századi Magyarországon, Történeti Demográfiai Évkönyv, Budapest 2005, 159.

${ }^{15}$ Faragó T., Bevezetés a történeti demográfiába.

${ }^{16}$ Katus László, Népesség, etnikumok, Szultán és a császár birodalmában, Magyarország mủvelődéstörténete 1526-1790 (Ed. Szentpéteri József), Budapest 2000, 341.
} 
година.

\section{Демографски губици}

Савремени извештаји, путописи, хришћански и османски пописи пореских обвезника и историографска дела говоре о материјалним разарањима широких обима, о пропадању култивисаних земљишта, а нарочито о изузетно тешким демографским последицама ратова и османске власти.

Демографске губитке можемо приближно проценити на основу броја становника на почетку и крају разматраног периода. У том смислу најбоље референце су пописи из 1494-1495, 1598, 1715. и 1784-1785. године који пружају најквалитетније податке.

Коморски попис из 1494-1495. године саставио је печујски бискуп, краљевски коморник Жигмонд Ернуст и садржи податке пореских обавеза приближно три четвртине становништва (40 од 54 жупаније) Краљевине Мађарске, заједно са Славонијом и Ердељом. На основу података пописа број становника се процењује на 3,5-4 милиона. ${ }^{17}$ Конскрипција кућа из 1598. г. пружа податке приближно за половину Угарске: за 22 жупаније подаци су сачувани комплетно, за 9 делимично. Анализа пописних података упућује на тешке последице ратова: и уз допуне недостајућих података једва се долази до броја од 3,5 милиона, ниже апроксимативне вредности за 1495. годину. Тај мањак вероватно настаје услед чињенице да је попис настао у тешко ратно време, у којем нису могли бити сви пописани, односно да су конскрипцијом забележени и актуелни губици становништва. ${ }^{18}$

Подаци пописа из 1715. године сугеришу још мањи број становника, свега нешто између 2,3 до 3 милиона. У вези са сва три наведена пописа постоји приличан број интерпретација и процена, али мађарски историчари се слажу у вези са главним тенденцијама током посматраног периода. У том смислу, већина сматра да при крају $\mathrm{XV}$ века Угарска није имала више од 4 милиона становника, да се чини да је током XVI века до почетка Петнаестогодишњег рата постојао благи пораст (при чему је тај раст знатно заостајао за европским просеком); да је Петнаестогодишњи рат имао катастрофалне демографске резултате који су имали дугорочне последице; да је број

\footnotetext{
${ }^{17}$ Конскрипција је поред кметова обухватала желире са кућом, ситне племиће са поседом од једне сесије као и становнике градова и трговишта. Нису међутим пописани свештеници, редовници, монахиње, племство и барони. Приликом интерпретације података пописа добро је имати на уму да је рађен после крвавих унутрашњих борби у Мађарској 1490-1491. године, односно да је настао у време када је и у другим европским земљама била привредно-друштвена криза, а у току процес депопулације села. Приметимо да је у складу са актуелном тенденцијом мађарске историографије која број становника током средњег века и ране модерне историје процењује ниже него раније, део историчара за 1495. годину сматра најприхватљивијом бројку од 2,9-3,3 милиона становника, од којих је 89,5\% било католика (Мађара, Хрвата, Немаца, Словака), 10,1\% православних (Румуни, Срби, Русини) и 0,4\% Јевреја. Kocsis Károly, $A$ Kárpát-medence vallásföldrajza (15-20. sz.), чланак у електронском формату: http://www.ittvagyunk.eu/htmls/cikkek.html?articleID=15.12.05.2014.

18 Held József, Hányan éltek Magyarországon a középkorban, História, Budapest 1991-056, електронска верзија: http://www.tankonyvtar.hu/hu/tartalom/historia/91-056/index.html. 12.05.2014; Zimányi V., Op. cit., $288-291$.
} 
становника до Бечког рата стагнирао, евентуално мало порастао, односно да је после Карловачког и Сатмарског мира услед ратних операција и велике епидемије куге пао на нижи ниво од оног пре 1683. г. При томе треба да имамо у виду да је број усељеника у овом периоду износио најмање пола милиона, па су губици домаћег становништва евидентни и поражавајући: не само да је изгубљен комплетан природни прираст становника током готово два века, већ је број почетног становништва смањен за приближно $12,5 \%$.

Тешки демографски учинак ратова и османске власти нарочито је видљив уколико га упоредимо са демографским растом у другим европским земљама. Прихватајући процену да је Угарска око 1500. године имала приближно 4 милиона становника, што је чинило 5,8\% становника Европе, а пред почетак Бечког рата максимално 4,2 милиона становника (3,8\% европског становништва), проценат пораста становништва би за 180 година износио 5\% (заједно са приливом миграната) наспрам европског просека од $58,7 \% .{ }^{19}$ Да је у истом периоду прираст становништва Угарске био на нивоу европског просека, пред почетак Бечког рата број становника би требало да се креће око 6,3 милиона (без усељеника). Постојећа разлика приближно илуструје губитке Угарске 1500-1680. године. Величину негативног демографског биланса повећава околност да су друге европске земље такође имале губитке: у XVII веку у целој Европи забележен је пад стопе пораста становништва услед захлађења климе, Тридесетогодишњег рата и бројних других ратова, епидемија куге, лошег рода житарица током више година и сл., али је пораст становништва ипак био неупоредиво већи од оног у Угарској. ${ }^{20}$

Паралелно са подацима о девастацији области под османском управом новија истраживања указују на закључак да је на територијама мање оптерећеним ратним дејствима постојало витално становништво способно за регенерацију и надокнаду губитака, чак са тенденцијом динамичног бројчаног раста, слично другим европским земљама. У областима северне Мађарске становништво се готово дуплирало током XVI века (у томе је наравно удео имала миграција са османских области на поменуте територије), а биле су релативно заштићеније и области Кнежевине Ердељ. ${ }^{21}$

\section{Промене у мрежи насеља}

Услед бројних ратова и османске власти мрежа насеља средњовековне Мађарске претрпела је знатне измене, највише на јужним и средишњим областима земље, односно на правцима наступања великих војски и дуж речних долина. Територије припојене Османској империји сем ратних пустошења морале су да

\footnotetext{
${ }^{19}$ Wellman Imre, Magyarország népességének fejlödése a 18. században, Magyarország története 1686-1790 (Eds. Ember Győző, Heckenast Gusztáv), I, Budapest 1989, 25; Zimányi V., Op. cit., 286-287.

20 Број становника Француске у исто време био је 18 милиона, Енглеске приближно 5 милиона, становништво северноамеричких колонија око 1,6 милиона, Шведске 1,6 милиона а Русије 13 милиона. Bódi Ferenc, Migrációs folyamatok az újkori Magyarországon, A helyi szociális ellátórendszer (Ed. Bódi Ferenc), Budapest 2008, 323.

${ }^{21}$ H.Németh I., Op. cit., 134.
} 
подносе бројне изазове османске власти и терете готово сталних пограничних сукоба. Такође, пустошења током Петнаестогодшњег и Бечког рата, односно Ракоцијевог устанка, била су најтежа у истим областима. Размере и карактер пропадања били су озбиљнији од других регија Угарске, што се примећивало поред осталог у променама крајолика и запуштености обрадивих површина, а надасве у чињеници да је 70-80\% насеља уништено или је опустело на дуже време. Мрежа насеља постала је изразито ретка, а број становника мали.

Генерално гледано, на територији Краљевске Мађарске није било тако дубоких промена, али је после ратова 1591-1606. и 1683-1699. године дуж војних путева и дуж линије фронтова чак и овде забележено уништење до 50\% насеља. Слично, током већег дела посматраног периода територија Ердеља је била релативно поштеђена великих ратних разарања, али је и она тешко страдала током Петнаестогодишњег рата и узастопних османских похода на Ердељ 1658-1662. године. $^{22}$

Уз пропадање насеља, најкарактеристичнија појава на запоседнутим областима било је груписање становништва у мањем броју већих села и трговишта. Усељавања становништва у већа села или трговишта нарочито је било карактеристично за период после Петнаестогодишњег рата, што смо већ горе поменули. Трговишта је на османским територијама било двадесетак и привлачила су превасходно становништво суседних разорених или угрожених села, али и становнике из других жупанија. Када посматрамо депопулацију села у турском периоду, треба да имамо на уму чињеницу да становништво разорених или напуштених села није комплетно страдало, већ да се један њихов део уселио у трговишта. ${ }^{23}$

Важна промена током османског периода историје Угарске била је темељита промена хијерархијске структуре градских насеља. Од некадашњих седам најважнијих градских центара (Будим-Пешта, Пожун-Шопрон, Кӧrmöcbánya, Кошице, Велики Варадин, Сегедин и Печуј) три су постали османски погранични градови (Будим-Пешта, Печуј и Сегедин), а Велики Варадин је дошао под управу ердељског кнеза. Мађарско и немачко грађанство, које је имало важну улогу у претходним временима, већином се иселило са османских области на хабзубуршке, чиме се и њихова делатност преместила у друге делове земље. Паралелно с тим, порастао је значај одређених пограничних насеља, попут Дебрецина и Ђера. Неки од краљевских градова стекли су значај као политичка и финансијска средишта: нова престоница Пожун, центар горње Мађарске Кошице (Kassa) и привремено седиште естергомског надбискупа Нађсомбат. Захваљујући узгоју и трговини стоком, на османским територијама нов значај добила су насеља са дотад друго и трећеразредним значајем попут Толне, Кечкемета, Мезетура (Mezötúr), Макоа, итд. ${ }^{24}$ Упечатљива последица османске власти и ратних дејстава било је уништење или гашење средњовековних културних центара при дворовима аристократије и

\footnotetext{
${ }^{22}$ Katus L., Op. cit., 342; Pálffy G., Op. cit.

${ }^{23}$ Makkai László, Táj és népek, Magyarország története 1686-1790 (Eds. Ember Győző, Heckenast Gusztáv), II, Budapest 1989, 1448-1449.

${ }^{24}$ Pálffy G., Op. cit.
} 
самостанима. Докраја 1560-их година претежна већина племства напустило је османске области, а црквене установе су услед ратних сукоба пропале не само на турској територији већ и у близини граници на хабзбуршкој страни. Примера ради, до 1570. г. нестало је свих сто средњовековних самостана веспремске црквене жупе, а од преко 600 парохија опстало је само неколико десетина. Тежак губитак црквених установа и блага мађарска католичка црква није успела надокнадити ни после Карловачког мира. Радикално смањење њене моћи помогло је брзом ширењу протестантских учења на османским областима. ${ }^{25}$

\section{Миграције и промене у етничкој структури становништва Мађарске}

Унутрашње миграције као и имиграција странаца у историји Угарске нису биле неуобичајене, али све до средине XV века оне нису имале већи обим него у другим савременим европским државама. Смер тих миграција до средине XIX века готово је увек био у правцу Угарске, а не из ње. Османска освајања на Балкану а касније у самој Угарској, међутим, довела су до веома живих, сложених и масовних миграторних кретања која су трајала све докраја XVIII века. Та померања становништва битно су утицала на историју Угарске у новом веку, а одвијала су се у више фаза.

Први приметан покрет становништва изазван османском територијалном експанзијом била је имиграција разног балканског становништва (Влаха, Срба, католичких Босанаца, Хрвата, Бугара, итд.), дуж дугих јужних граница, у Угарску. Интензитет усељавања повећавао се после Косовске битке, односно после пада Српске деспотовине. Паралелно са поменутом имиграцијом одвијало се проређење (због погибије и одвођења у ропство) и миграција староседелачког становништва на мање изложене, сигурније северне области, услед све разорнијих турских напада на јужне крајеве земље.

Битне промене донеле су деценије после Мохачке битке, а нарочито после 1541. године када су средишње области Краљевине Мађарске и источни делови хрватских земаља припојене Османској империји. Претежан део племства, имућније становништво, грађани и део житеља вароши се из јужних и средишњих делова Угарске преселило у северне и западне делове земље под влашћу Хабзбурга. Многи сељаци и варошани определили су се за службу на војној граници која је управо настајала или за службу у војскама великаша. Неки младићи су се одметнули у хајдуке, што је такође било везано за напуштање своје уже патрије. ${ }^{26}$ Сељаштво које

\footnotetext{
${ }^{25}$ Ibidem.

${ }^{26}$ Услед ратних пустошења, нарочито током Петнаестогодишњег рата, многи младићи који су остали без дома или земље одлазили су у хајдуке у хабзбуршким и у османским областима. Палатин, гроф Иштван Илешхази, извештавао је о њима у области Шомођа и Барање где су, како наводи, извршили бројна витешка дела против Турака. Његове наводе потврђују подаци турског хроничара Печевија који је у раду насталом 1641-1651. г. писао да су се сви снажни момци из раје одметнули у хајдуке и да су опсели вароши између Будима и Београда и да се због њих из једне у другу паланку може ићи само уколико се окупи војска од 500-600 људи. Примећује да и он сам у Печују, кад падне мрак, у кревет леже са сабљом и пушком. Без обзира на немилосрдне прогоне, хајдуци су се одржали до Бечког рата, а били су активни против Османлија и током Бечког рата. Makkai L., Op. cit. 1438-1439.
} 
се није одселило у области под хришћанском влашћу, често се селило у оближње градове и трговишта, који су нудили више сигурности и одређене пореске олакшице. Археолошка истраживања указују на то да је било доста сељака који су формирали ново насеље недалеко од својих некадашњих села, али одвојених од тих села и главних саобраћајних праваца шумама, водотоковима и мочварама, те су нова села нестала из видокруга војника, порезника и путника. Сељаштво које је опстало на османским територијама бавило се земљорадњом у мери у којој је то било неопходно за преживљавање, а све више се оријентисало на сточарство, због сигурније зараде и с обзиром на то да се у случају опасности могло склонити на заштићенија места заједно са својом имовином. ${ }^{27}$

После 1541. г. селидба Балканаца на османске окупиране области Угарске постала је заправо унутрашња миграција унутар Османске империје која више није била подстицана бежањем испред османске власти, већ унутрашњим политичким и социјалним односима саме Османске империје. ${ }^{28}$ Балканско становништво које је и даље желело да мигрира на хришћанске територије уместо јужне Угарске одлазило је у Кнежевину Ердељ, у делове Угарске под хабзбуршком влашћу, у правцу пољсколитванске уније или млетачке Далмације.

Усељавање странаца у поменуте области, између осталих разлога, подстакнули су финансијски интереси властеле која је тежила ревитализацији области погођене депопулацијиом и што бржој обнови производње. Та пракса јавила се још пре 1526. г. колонизацијом сељака у јужне области земље, пре свега у Срем, Бачку, Банат и делове Задунавља. У областима западно од Дунава велепоседници су нарочито од 1530-их до 1540-их година насељавали католичке Хрвате избегле од турске опасности, те их је у наредним деценијама у западну Мађарску стигло неколико десетине хиљада и населило се раштркано од Међумурја до Пожуна. ${ }^{29}$

У Задунавље су стизали и Власи с посебним влашким правима, при чему су се они насељавали у одвојеним насељима како од Мађара тако и од Хрвата. Проширили су се на север до језера Балатон, на чијем јужном ободу се 1581. г. налазило већ 84 влашка (Ифлак) села. ${ }^{30}$

На ратовима проређене данашње територије Бачке, Баната и Барање стигли су бројни насељеници са Балкана, пре свега Срби. Њихова етничка граница се до Петнаестогодишњег рата усталила на линији Баја - Сегедин - река Мориш, испод које су чинили већину становништва, а северније од ње живели су у мањем броју и

\footnotetext{
${ }^{27}$ Wellman I., Op. cit., 46.

28 Један од мотива пресељења осветљава тахрир дефтер из 1560-1561. године, који садржи наредбу султана Сулејмана Величанственог о насељавању припадника раје и „лутајућег шатровачког народа“ у места Боршод, Гара и Арањаш. Одлуку образлаже намером да осигура заштиту области између Баје и Сомбора опустелој током његових претходних похода. У наредби са наводи да хајдуци коњаници и пешаци из тврђаве у Јегру, Ђули и Сигетвару узнемиравају народ и путнике у том крају, те да треба оживети поменута три насеља у којима ће бити стационирано 100 коњаника, који ће у заузврат за војну службу бити ослобођени од свих редовних и ванредних пореза и служби. Wicker Erika, Rácok és vlahok a hódoltság kori Észak-Bácskában, одбрањена докторска дисертација, Eötvös Loránd TudományegyetemBölcsészettudományi Kar, Budapest 2006, 20.

${ }^{29}$ Pálffy G., Op. cit.

${ }^{30}$ Makkai L., Op. cit., 1441-1444.
} 
раштркано насељени. Покушаји османских власти да створе сталне српске насеобине северно од те линије докраја XVI века показали су се неуспешним. ${ }^{31}$ Вакуум који је настао уништењем мађарских насеља током Петнаестогодишњег рата створио је повољне околности за проширење Срба у северније области средњег дела Мађарске, па је палатин Естерхази крајем 20.их година XVII века извештавао бечки двор о томе да су најсевернија станишта Срба код Шимонторње и Дунафелдвара, да од ових градова на југ они живе измешано са Мађарима, а да јужно од Мохача има готово само Срба. ${ }^{32}$

Порасту сразмере муслимана и православних у Угарској допринела је изградња османског правног и социјалног поретка на анектираним угарским областима. С обзиром на то да католици и протестанти нису учествовали у османској војној и државној организацији, комплетна владајућа структура добила је османски, муслиманско-православни карактер. При томе елитне војне јединице и спахије су били муслимани (истина, међу њима је било 15-30\% балканских конвертита), док су у саставу мартолоца и асапа, речне флоте и артиљерије ангажовани бројни православни Словени. Раја, занатлије, трговци у етничком и верском смислу били су прилично шарени. Већина муслиманског становништва османских области населила се у шездесетак тврдих градова, који су представљали уједно и црквене, административне и културне центре, а остатак у 20-30 мањих војних насеља. Немамо изворе који би потврђивали присуство османске властеле у селима. ${ }^{33}$ Није било планског насељавања муслимана, али се дешавало да у околини стратешки важних тврђава Порта замени мађарско становништво муслиманима или православним становништвом у служби османске војске, као што се то десило насељавањем Срба у околину Естергома, Вишеграда, Секешфехервара, Велике Кањиже или Сигетвара, односно њиховим насељавањем у мање тврђаве на стратешки важној десној обали Дунава. ${ }^{34}$ Протоком времена сразмера Јужних Словена у окупационом војно-привредно-управном систему био је све већи. Према рачуницама Давида Гезе, укупан број немађарског становништва у османским областима Мађарске крајем XVI века износио је око 360.000 , односно 40\% укупног становништва. ${ }^{35}$

У области Кнежевине Ердељ и Парцијума имигрирали су у великом броју Румуни, а делом Срби, при чему су то усељавање подстицале такође ратне операције, највише Петнаестогодишњи рат и економски интереси племства. Повољне околности живота у Трансилванији имале су сталну привлачну снагу на Румуне у Молдавији и Влашкој, те је њихов прилив био константан. Румуни из поменуте две кнежевине представљали су непресушни резервоар нових имиграната, као што је Балкан имао сличну улогу за досељавање Јужних Словена.

\footnotetext{
${ }^{31}$ Wicker E., Op. cit., 19-20.

${ }^{32}$ Makkai L., Op. cit., 1432; Pálffy G., Op. cit.

${ }^{33}$ Sinkovics István, Három országrész irányitása, Magyarország története 1526-1686 (Ed. Pach Zsigmond Pál), I, Budapest 1987, 455-456.

${ }^{34}$ Sinkovics I., Op. cit., 457-458.

${ }^{35}$ H.Németh I., Op. cit., 136, цитирао је Гезу Давида: Dávid Géza, Magyarország népessége a 16-17. században, Magyarország történeti demográfiája 896-1995. Millecentenáriumi előadások (Ed. Kovacsics József), KSH, Budapest 1997, 141-171, 167-169.
} 
Већ смо констатовали да су најважнији подстицај усељавању из околних земаља били огромни људски губици изазвани бројним ратовима у XVI и XVII веку. Стицајем околности ратови су највише погодили мађарско становништво. Оно је настањивало средишње области земље поред токова великих река, поред сувоземних путева, односно живели су на правцима проласка великих османских војски, али и хабзбуршких царских армија током два дуга рата. Најдуготрајнији и најжешћи напади погађали су претежно јужне и средишње области Мађарске које су у средњем веку биле густо насељене и богате, са претежно мађарским становништвом. ${ }^{36}$ Мађари су чинили већи део пограничне војске са аустријске стране северно од Драве, која је имала тешке губитке у век и по дугим борбама са Османским царством. Уз то, Мађари су масовно гинули у ратовима и устанцима против Хабзбуршке власти у XVII веку, односно њих су погађале крајње тешке репресалије по верској основи 1670-1685, односно за време Бечког рата и Ракоцијевог устанка. Истовремено, губици немађара који су становали на периферним, претежно планинским областима земље били су знатно мањи, те се код њих у историјским изворима примећује демографски раст, сличан оном који је карактерисао европске земље у XVI веку.

Велико опадање сразмере Мађара у односу на немађаре услед помињаних миграција и губитака било је уочљиво у променама етничких простора: на југу земље мађарско-српска језичка граница померила се за више од стотину километара према северу, а слично и румунска-мађарска према западу. Померања језичке границе Словака и Русина пре Сатмарског мира била су мањег обима, али су и она износиле приближно 30-40 километара. Генерално, смањиле су се области са мешовитим мађарско-немађарским станоништвом у корист чисто народносних територија, које су се географски знатно увећале. ${ }^{37}$

\section{Бечки рат и Ракоцијев устанак}

Бечки рат и Ракоцијев устанак имали су посебно тешке консеквенце по становништво Угарске. Оба рата трајала су дуго, укупно 24 године, и обухватала су целу територију земље. ${ }^{38}$ За њих су биле карактеристичне све тешкоће које су постојале у време Петнаестогодишњег рата, с тим да је било нових елемената који су тежину ситуације даље погоршали. У Бечком рату то је био измењен однос Османлија и бечког двора према Угарској, а у Ракоцијевом ослободилачком рату међусобан истребљивачки рат Мађара и Срба и једна од најпогубнијих епидемија куге. У смислу страдања и разарања поменуте три деценије можда су најгори период

\footnotetext{
36 Замена мађарских назива у Срему може се пратити у изворима од друге половине XIII века. До средине XIV века Срем добија претежно српски карактер, а у ужем појасу на југу Бачке и Баната у том периоду Срби живе измешано са Мађарима. Szakály Ferenc, Szerbek a középkori Magyarországon, História, Budapest 1991-023.

${ }^{37}$ H.Németh I., Op. cit., 140.

38 Заправо, ратне прилике су у северним и североисточним деловима земље трајале готово непрекидно четрдесет година, с обзиром на то да је овде од 1672. био у току Куруцки устанак.
} 
историје Мађара и Мађарске. ${ }^{39}$

Код Османлија је после хришћанског ослобађања Будима и битке код Нађхаршања 1687. г. превладало мишљење да су дани њихове власти у Карпатској котлини одбројани, те више нису имали ни минималног обзира према локалном становништву: османска војска је пљачкала, палила, одводила становништво у ропство. Ситауцију је погоршала околност да је доста османских тврђава остало изоловано у позадини фронта, одсечено од линије снабдевања, те су немилосрдно утеривали све врсте давање од становништва. На путевима војних операција пропадало је и оно што је уз доста тешкоћа сачувано у претходним временима. ${ }^{40}$

Важан разлог тежине страдања становништва и земље био је негативан однос бечког двора према мађарским сталежима и генерално према земљи. Разочаран сталном опозицијом сталежа, устанцима и заверама против своје политике, цар Леополд I желео је да током рата спорна питања хабзбуршкомађарских односа коначно реши у корист своје династије. У складу с тим је било и понашање аустријске војске према земљи и локалном становништву, а главни терет смештаја савезничке војске пребачен је на Угарску - она је истовремено постала снабдевач војске и бојно поље, била је обавезана на 2/3 пореских прихода разрезаних на целу Аустријску монархију. ${ }^{41}$

Резултат те политике су била разарања која су превазилазила све дотад виђено. Ситуација је била тешка до те мере да су цара опомињали њему најлојалнији сарадници да су злодела стациониране царске војске неиздржива. Наводили су да највише проблема стварају огромна висина пореза, његово насилно и крајње брутално утеривање путем војне егзекуције, злодела пролазеће војске, а надасве у мађарским насељима стациониране трупе, чије насилничко понашање прети уништењем преосталог становништва. Војни судија Јохан Николаус Фламицер, полузванични говорник бечког двора, констатовао је да се савезничка војска у Угарској понаша као да јој је задатак уништавање, а не заштита хришћанског становништва, да тврдоћа и немилосрдност њихових поступака далеко прелази све што је овај народ морао да претрпи од исконског непријатеља хришћана, од Турака. ${ }^{42}$ Извори сведоче о томе да је на појединим газдинствима $38-50 \%$ сељака

\footnotetext{
${ }^{39}$ R. Várkonyi Ágnes, Török háború Bécstöl Budáig 1683-1686. Magyarország története 1686-1790 (Eds. Ember Győző, Heckenast Gusztáv), II, Budapest 1989, 1581.

${ }^{40}$ Wellman I., Op. cit., 25-27; H. Németh I., Op. cit., 138.

41 Бечки двор је издражавање војске желео решити директним снабдевањем храном, разним потрепштинама, подвозом и смештајем на лицу места. Двор је налазио новац и на друге начине: приликом опсаде Беча потрошено је мађарско црквено благо, насилно су узимани кредити од државних чиновника, од палатина, племића, градова. Примера ради, калвинистички Дебрецин оптерећен је са укупно 960.000 форинти, што је било више него што су платиле три најбогатије државе Немачко-римског царства, Вестфалија, Бургундија и Доња Саксонија. R. Várkonyi Á., Op. cit., 1608, 1611-1612; R. Várkonyi Ágnes, A királyi Magyarország 1541-1686, Budapest 1999, 156.

42 У вези са поменутим ексцесима од 1685. јављао се отпор становништва и све су уобичајенији били крвави сукоби између војника и становника. Млетачки посланик Корнаро је фебруара 1686. године своју владу извештавао о све учесталијим већањима унутар мађарског племства о актуелним збивањима и да се шаљу изјаве бечком двору да су сталежи спремни без ограничења заложити се и ризиковати све за ослобођење земље, али да више неће трпети уцене, пустошење и анархично стање у земљи. R.Várkonyi Ágnes, Török háború Bécstől Budáig 1683-1686, Magyarország története 1686-1790 (Eds. Ember Győző, Heckenast Gusztáv), II, Budapest 1989, 1611, 1616.
} 
нестало. Један званичан извештај бечкој влади из 1698. године говорио је о потпуној пропасти становништва Мађарске. ${ }^{43}$

Уз поменуте страхоте не би требало да заборавимо два велика и трагична покрета становника током Бечког рата: протерано цивилно муслиманско становништво ослобођених области померало се према Балкану, а шездесетак хиљада Срба селило се у бојазни од османског зулума са својих огњишта на Косову и Метохији, Рашкој, Старој Србији на угарске територије северно од Дунава и Саве. $^{44}$

Током Ракоцијевог устанка понављали су се атроцитети према становништву већ виђени у пређашњем рату. Развила се борба у којој живот појединца није значио ништа. Командант војске у Ердељу, гроф Жан Луј Рабутин, издао је наредбу да у насељима где становништво не буде измирило разрезани порез и давања у намирницама треба посећи и жену и децу. Устаници су узвраћали истом мером. $^{45}$ Посебно је значајно да је бечки двор разним мерама успео да подстакне Србе на борбу против устаника. Ређали су се напади и контранапади с обе стране, при чему је интензитет сукоба био толики да су на југу земље бројна мађарска села нестала а српско становништво је десетковано. Сам Ракоци је 1707. г. изјавио да су Срби нанели више штете устанку и мађарском становништву него цела царска војска. ${ }^{46}$ По савременим изворима војни губици устанка износили су укупно 85.000 лица у Мађарској и преко 10.000 погинулих у Ердељу. ${ }^{47}$

Вишеструко веће губитке од ратних дејстава нанела је епидемија куге која је харала током Ракоцијевог устанка 1708-1711. г. Савременици су број помрлих ценили на 300.000 до 1,5 милиона, док данашњи историчари губитке процењују на 150.000 до 500.000. Епидемија је задала тежак ударац устанку који је управо 1708 . улазио у фазу кризе. ${ }^{48}$ Један од вођа ослободилачког рата, гроф Миклош Берчењи, можда је у намери да оправда опадање снаге покрета, али свакако свестан тежине епидемије, приметио да је устанике победила куга, а не немачка војска. ${ }^{49}$

Демографске консеквенце готово тридесетогодишњег периода Бечког рата и Ракоцијевог устанка биле су веома озбиљне. После Сатмарског мира у земљи је живело неколико стотина хиљада становника мање него 1683. године - 1711. у Угарској је у најбољем случају било до 3,8 милиона становника. ${ }^{50}$

\footnotetext{
${ }^{43}$ R. Várkonyi Á., Op. cit., 1615.

44 Душан Т. Батаковић, Нова историја српског народа, Београд 2002, 117; Kocsis K., Op. cit.

${ }^{45}$ H. Németh I., Op. cit., 139; Wellman I., Op. cit., 28-31.

${ }^{46}$ Wellman I., Op. cit., 31-34.

${ }^{47}$ Kapronczay Károly, Népesség - járványok, Történeti Demográfiai Évkönyv, Budapest 2001, 423.

${ }^{48}$ Пошто је куга погађала градове, градско становништво, али и војска је бежала из њих. Уколико је војска остајала у граду или тврђави, често је трпела толике губитке да је њена снага анулирана. Како би избегли знатне губитке, Ракоцијеви официри су веће војне јединице делили на мање, али с тим су снижавали ударну моћ својих трупа. Опсада Ершекујвара је морала бити прекинута, јер је бројност Ракоцијеве војске услед куге са 16.000 спала на 3.000 војника. Због епидемије, било је крајње отежано прикупљање добровољаца и пореза, итд., Schultheisz Emil (priredio za štampu Gazda István), Fejezetek az orvosi mûvelõdés történetébõl, Piliscsaba 2006, 201.

${ }^{49}$ Faragó Tamás, Bevezetés a történeti demográfiába, http://www.tankonyvtar.hu/en/tartalom/tamop425/0010 2A_09_Farago_Tamas_Bevezetes_a_torteneti_demografiaba/ch06s02.html\#id543663. 12.05.2014.

${ }^{50}$ Wellman I., Op. cit., 39, Bódi F., Op. cit., 323.
} 


\section{Почетак демографског опоравка}

Закључење Сатмарског мира 1711. је уз завршетак Ракоцијевог рата и успостављања коректних односа двора и мађарских сталежа у дужој историјској перспективи значило и завршетак готово два века погубног ратовања на територији Угарске, која од тада па до Револуције 1848/49. године није трпела већа ратна збивања. Угарска је као део Хабзбуршке монархије учествовала у њеним бројним и тешким ратовима у XVIII веку, али више није била бојиште сучељених империја и није претрпела људске или материјалне губитке ни приближног обима онима из претходног историјског периода.

Штовише, XVIII век показао је велику виталност становништва Угарске. После разочаравајуће ниског броја становника забележеног у попису становништва 1715. године - који је додатно наглашавала чињеница да је на бившим османским областима пописано несразмерно мање насеља и породица него у областима Краљевске Мађарске и Ердеља - резултати пописа становништва из 1785. године умногоме су изненадили савременике, а још и данас збуњују историчаре. ${ }^{51}$ Савременици су пре пописа број становника Угарске без Ердеља процењивали на свега 3,2 милиона, а јозефински попис је регистровао 9.265.185 житеља, без војске, која је бројала преко 260.000 људи. ${ }^{52}$

Брз раст становништва био је у складу са европским демографским тенденцијама (током XVIII века број становништва Европе се повећао са стотинак на близу две стотине милиона), али пораст становништва Угарске од преко $250 \%$ био је импресиван чак и онда ако имамо на уму масовно усељавање из румунских кнежевина, Пољске, српских области под Османлијама и Немачког царства. Уз прилив колониста, чији укупан број већина историчара цени на више од милион лица, брз раст уследио је као резултат консолидације унутрашњих политичких односа, измештања бојишта великих сила ван граница Угарске и општег побољшања животних услова, здравствених прилика. ${ }^{53}$

Уз поменуте елементе мађарски историчари као важан подстицај смањењу социјалне тензије и као значајан елемент позитивно мотивисаног и динамичног развоја привредне делатности наводе важност унутрашње миграције, током које су житељи густо насељених области Угарске мигрирали у правцу некадашњих османских, ретко насељених територија, где је постојала непресушна потреба за радном снагом и култивацијом широких, а крајње запостављених земљишта.

\footnotetext{
51 Први попис становништва после Сатмарског мира извршен је 1715. г., а услед мањкавости начина конскрипције поновљен је 1720. г. Од укупне територије Угарске попис није обухватао Ердељ, Хрватску,

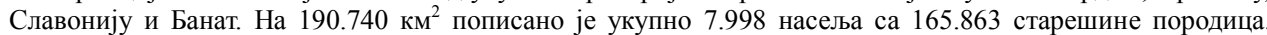
Раније турске области чиниле су нешто више од трећине пописане територије, али на њима се налазио само $13 \%$ насеља и $20 \%$ становништва, док је на областима под хабзбуршком влашћу без војне границе (44\% пописане територије) било готово две трећине $(65,34 \%)$ насеља и мало више од шездесет \% $(60,15 \%)$ старешина породица. Wellman I., Op. cit., 41-43.

${ }^{52}$ Wellman I., Op. cit., 72-73.

${ }^{53}$ Kosáry Domokos, Újjáépités és polgárosodás 1711-1867. Magyarok Európában III., Budapest 1990, 55.
} 
Демографска кретања пре, током и после периода ратова и османске власти на територији Угарске указују на тежину губитака у проучаваном периоду: пре и после 1521-1718. примеђује се раст становништва сличан европским трендовима. Штовише, раст се уочава на областима и у периодима без великих ратова чак и у османско доба. С друге стране, дуготрајни ратови (1591-1606, 1683-1699, 1703-1711, па и 1658-1662) имали су крајње негативне последице по становништво. Огромни губици у 21 рату узроковали су стагнирање броја становника током 180 година, чак и уз усељавање становника из околних земаља реда величине више стотина хиљаде лица.

Директна последица чињенице да су ратна дејства најтеже губитке нанела мађарској популацији и масовне имиграције била је темељита промена етничког састава становништва Угарске, при чему је сразмера Мађара са 75-80\% спала на свега $50 \%$, са тенденцијом даљег опадања због наставка имиграције, при чему се у XVIII веку у земљу уселило преко милион особа. Током разматраног периода нарочито је порасла сразмера Срба и Румуна (Словака и Русина у мањој мери), а током XVIII века уз њих осетно је повећан односа Немаца и Јевреја у укупном броју становника. Резултат тог развоја била је промена карактера државе, настанак изразито мултиетничког, мултиконфесионалног и мултикултуралног друштва са свим проблемима који су из тога проистекли у доба продора национализма од прве половине XIX века.

\section{Литература:}

Батаковић, Душан Т., Нова историја српског народа, Београд 2002.

Bódi Ferenc, Migrációs folyamatok az újkori Magyarországon, A helyi szociális ellátórendszer (Ed. Bódi Ferenc), Budapest 2008, 321-332.

Dávid Géza, Magyarország népessége a 16-17. században, Magyarország történeti demográfiája, 896-1995. Millecentenáriumi előadások (Ed. Kovacsics József), Budapest 1997, 141-171, $167-169$

Ђере, Золтан, Од Мохачке битке до смрти ичара Јозефа II, Историја Мађара (П. Рокаи, 3. Ђере, Т. Пал, А. Касаш), Београд 2002, 184-380.

Faragó Tamás, A magyarországi történeti demográfiai kutatás vázlatos története. I. A kezdetektöl 1945-ig, Történeti Demográfiai Évkönyv, 2006-2008, Budapest 2008, 5-40.

Faragó Tamás, Adatok a pestisjárványok magyarországi történetéhez, Korall, 8. год., бр. 30, Budapest 2007.

Faragó Tamás, Bevezetés a történeti demográfiába, Budapesti Corvinus Egyetem, електронска књига, http://www.tankonyvtar.hu/en/tartalom/tamop425/0010_2A_09_Farago_Tamas_Bevezete S_a_torteneti_demografiaba/ch06s02.html. 12.05.2014.

Font Márta, A honfoglalástól Mohácsig, A Kárpát-medence etnikai és demográfiai viszonyai a honfoglalástól a török kiüzéséig (Ed. Font Márta), Pécs 1998, 1-13. 
Granasztói György, Történelem és történetírás. Jegyzet arról, hogyan változik az ország lélekszáma hosszú idötartam alatt, Történeti Demográfiai Évkönyv, Budapest 2005, 9-20.

Kapronczay Károly, Népesség - járványok, Történeti Demográfiai Évkönyv, Budapest 2001, 423-432.

Karasszon Dénes, Demográfiai mutatóink történelmünk korszakai szerinti ingadozása orvostörténelmi megvilágitásban, Történeti Demográfiai Évkönyv, Budapest 2001, 415-422.

Katus László, Népesség, etnikumok, Szultán és a császár birodalmában. Magyarország művelődéstörténete 1526-1790 (Ed. Szentpéteri József), Budapest 2000.

Kocsis Károly, A Kárpát-medence vallásföldrajza (15-20. sz.), чланак у електронском формату, http://www.ittvagyunk.eu/htmls/cikkek.html?articleID=15. 12.05.2014.

Kosáry Domokos, Újjáépités és polgárosodás 1711-1867. Magyarok Európában III., Budapest 1990.

Kováts Zoltán, A Kárpát medence népesedési viszonyainak alakulása (900-1870), Történeti Demográfiai Évkönyv, Budapest 2001, 121-129.

Kubinyi András, A késö-középkori Magyarország történeti demográfiai problémái, Történeti Demográfiai Évkönyv, Budapest 2001, 105-120.

Makkai László, Tájésnépek, Magyarország története 1686-1790 (Eds. Ember Győző, HeckenastGusztáv), II, Akadémiai Kiadó, Budapest 1989.

Németh István H., Háború és népesség a kora újkori Magyarországon (16-17. század), Történeti Demográfiai Évkönyv, Budapest 2001, 129-142.

Öri Péter, A pestisjárványok demográfiai következményei a 17-18. századi Magyarországon, Történeti Demográfiai Évkönyv, Budapest 2005, 115-162.

Pálffy Géza, A másfél évszázadnyi török uralom mérlege. A törökkor fordulópontjai 1, Múlt-kor, Internet časopis, 2001 3. sz.http://www.mult-kor.hu. 12.05.2014.

Sinkovics István, Három országrész irányitásam, Magyarország története 1526-1686 (Ed. Pach Zsigmond Pál), I, Budapest 1987.

Szakály Ferenc, Szerbek a középkori Magyarországon, História 1991-023.

Tóth István György, A felszabaditó háborúk, Nagy képes milléniumi hadtörténet (Ed. Rácz Árpád), Budapest 2008, 205-229.

Várkonyi Ágnes R., A királyi Magyarország 1541-1686, Budapest 1999.

Várkonyi Ágnes R., Török háború Bécstől Budáig 1683-1686, Magyarország története 1686-1790 (Eds. Ember Győző, Heckenast Gusztáv), II, Budapest 1989.

Vecsey Lajos, Az imádságok bullája és A déli harangszó, Genessenschafts-Buchdruck 1955, 32.

Wellman Imre, Magyarország népességének fejlödése a 18. században, Magyarország története 1686-1790 (Eds. Ember Győző, Heckenast Gusztáv), I, Budapest 1989.

Wicker Erika, Rácok és vlahok a hódoltság kori Észak-Bácskában, odbranjena doktorska disertacija, Eötvös Loránd Tudományegyetem Bölcsészettudományi Kar Budapest 2006.

Zimányi Vera, Gazdasági és társadalmi fejlödés Mohácstól a 16. század végéig,Magyarország története 1526-1686, (Ed. PachZsigmondPál), I, Budapest 1987. 


\title{
ZOLTÁN GYÖRE
}

\section{WARS AND THE POPULATION OF HUNGARY 1521-1718}

\author{
Summary
}

Due to the disintegration of the state, the decline of economic and social conditions, and above all large demographic losses, the epoch of Ottoman rule (15411718) in certain parts of the Kingdom of Hungary has been considered as the worst period in the history of Hungary and Magyars.

In the mentioned period 21 wars were waged on the territory of Hungary (Habsburg - Ottoman, Transylvanian - Ottoman, Habsburg - Hungarian). Despite the natural growth of the population and large-scale immigration from Balkans, as a result of the above mentioned conflicts, the number of Hungary's population had stagnated for more than one and a half centuries. In contrast, the average growth of European population in the same period was close to $60 \%$. Due to the heavy wartime destructions, the network of settlements has radically been thinned and structurally modified. As a significant result of the permanent war conditions and the massive immigration, the proportion of Magyars in the ethnic composition of the country's population had fallen from $75-80 \%$ to $50 \%$. The main result of this process was the emergence of a multi-ethnic, multi-religious and multicultural society, which has provoked the change in character of the state, as well the problems that have appeared in this multi-ethnic society in the age of nationalism.

Keywords: Ottoman Empire, Habsburg Monarchy, Hungary, historical demography, population number, wars, Vojvodina, migrations, settlements. 